\title{
Shelf-Life Extension of Nigerian Pepper (Capsicum Frutescens Linn and Capsicum Annuum Linn) Following Gamma Irradiation
}

\author{
OWOADE L.R. ${ }^{1}$, ADEMOLA J.A. ${ }^{2}$ \\ '(National Institute of Radiation Protection and Research,University of Ibadan Campus, Nigeria) \\ ${ }^{2}$ ( Department of Physics, University of Ibadan, Nigeria)
}

\begin{abstract}
The shelf-life extension of two types of Nigerian pepper (Capsicum frutescens linn and Capsicum annuит linn) was determined after gamma irradiation from a Cobalt-60 Gamma Irradiator, Model Gamma Cell 220. Capsicum frutescens linn "Atarodo, Hausa type" and "Atarodo, Ibadan local" were studied while Capsicum annuum linn "Sombo" was also studied within a period of fifty four days. The samples were irradiated with different gamma doses ranging from $0.5-4.0 \mathrm{kGy}$. The result obtained showed that, the shelflife extension of Capsicum frutescens linn "Atarodo Hausa type" is forty-two days, while that of Capsicum frutescens linn "Atarodo Ibadan local" is forty eight days while the shelf-life extension of Capsicum annuum linn "Sombo" is fifty-four days. The optimum dose for the shelf-life extension of the pepper studied was 1.0 $k G y$. The irradiation of these food composites has clearly revealed the merits of food preservation by irradiation through considerable shelf-life extension without degrading the quality of the food irradiated.
\end{abstract}

Key words: Capsicum annuum linn, Capsicum frutescens linn, optimum dose, shelf-life extension

\section{Introduction}

Two thirds of the world's population is inadequately fed and yet million of kilogrammes of food are wasted each year as a result of poor and inadequate storage and handling facilities [1]. Despite the availability of many established and widely used food processing technologies, developing countries are still experiencing high post-harvest losses of food. These losses are increasing annually, and it has created changing patterns in food consumption habits.

Fruits and vegetables like tomato, pepper, onion and orange are food items that are very vital in human diet, right from infants to the aged ones. The importance of these essential food items has brought about their preservation in order to spread their availability throughout the year.

Though many technologies are being employed for use in food preservation in order to reduce postharvest losses, these technologies have drawbacks in their applications which make them unsuitable for preservations or limit their use.

In an effort to reduce some of these losses, which cannot be thoroughly handled by other food preservations like canning, salting, smoking, drying, refrigerating and heat pasteurization, attention have been brought to food preservation by irradiation using X- or gamma rays or electrons which will control pests and microorganism, such as bacteria, yeast and moulds, causes delay ripening of these fruits and, thereby, extend their shelf-life [2]. Food borne diseases are prevalent in all parts of the world, and the toll in terms of human life and suffering is enormous [3].

Contaminated food contributes to 1.5 billion cases of diarrhea in children each year, resulting in more than three million premature deaths, according to the World Health Organization [3][4].

Food irradiation is a new novel technology to increase the safety of food. It is used for controlling spoilage and eliminating food borne pathogens such as Salmonella and E. colli [2].

This technology started shortly after the discovery of X-ray in the late 1800 s, researchers found that exposure of food to this radiation could kill some of the bacteria in it. Following the end of World War II, the U.S. Army initiated increased research into the uses of food irradiation [5].

\section{Materials and Method}

The pepper used for this work were planted under the same condition and harvested at their cultivarspecific physiological maturity, from the Teaching and Research farm of the Faculty of Agriculture, Obafemi Awolowo University(OAU), Ile-Ife and were taken to the Gamma Irradiation Laboratory, Centre for Energy Research and Development (CERD) for preparation and irradiation.

The pepper harvested were free of defects and were washed with pipe borne water, put in an open container to avoid temperature effect on them. It is important to use good agricultural and processing methods to ensure the cleanest and best quality ingredients, since increased dose may affect the sensory qualities of the spices, [6]. The pepper irradiated were of two sub-species of Atarodo, namely Atarodo Hausa (Capsicum 
frutescens linn) and Atarodo Ibadan local (Capsicum frutescens linn). The third type of pepper studied is Sombo (Capsicum аппиит linn). Each sub-species was packed in tens in polytene bags, cellotaped and labeled. This was to ensure that the oxygen content during packaging and irradiation was drastically reduced, thereby reducing possible oxygen effect [7].

The packaged samples were irradiated immediately, polytene bags removed and were stored in an open shelf in the laboratory at room temperature and low humidity.

There were a total of nine samples for each sub-species. Each sample was labeled according to the gamma dose to be delivered. The samples were irradiated with different gamma doses ranging from $0.5-4.0$ kGy, using Gamma Cell 220 at the CERD and were given three replicates. One of the nine samples of each subspecies was not irradiated and were labeled $0.0 \mathrm{kGy}$. The other eight packaged samples of each species were irradiated with gamma doses $0.5,1.0,1.5,2.0,2.5,3.0,3.5$ and $4.0 \mathrm{kGy}$ respectively.

The irradiation time for each sample was obtained using the relation:

Doserate $=\frac{\text { Dose }}{\text { Time }}$

The doserate for the irradiation $\mathrm{D}_{\mathrm{t}}$ was determined using the following relation :

$D_{t=} D_{0} e^{-\lambda t}$

Where $D_{0}$ is the Dose rate at the Centre of chamber as quoted by the supplier.

i.e. $\quad 1.82 \times 10^{4} \pm 0.12 \mathrm{~Gy} / \mathrm{hr}$ on February 15,1980 .

$\mathrm{t}$ is the time interval since the machine was supplied to date

$\lambda$ is the decay constant of Cobalt -60 .

III. Results and Discussion

After irradiation, observation of the spices for the process of rot was taken at an interval of three days. Observation for rot of Atarodo Hausa (Capsicum frutescens linn) lasted for forty-two days, that of Atarodo Ibadan local (Capsicum frutescens linn) lasted for forty-eight days while observation for the process of rot for Sombo (Capsicum annuum Linn) lasted for fifty-four days.

The result for the percentage rot for the investigated peppers are shown in fig.1 to16.

During the monitoring and evaluation for the percentage rot of Atarodo Hausa (Capsicum frutescens linn) and Atarodo Ibadan local (Capsicum апnиит Linn), it was observed that, during the first twelve days after irradiation the species of Atarodo Hausa and Atarodo Ibadan local got rotten fast at higher doses especially 3.0, 3.5 and $4.0 \mathrm{kGy}$, while the percentage rot was so small for lower radiation doses especially $0.5,1.0$, and 1.5 $\mathrm{kGy}$. On the $15^{\text {th }}$ day, gamma radiation doses of $0.5,1.0$ and $1.5 \mathrm{kGy}$ still enhances the preservation of pepper relative to the control that recorded 50 percent rot for Capsicum frutescens linn (Atarodo-Hausa type). Higher gamma radiation doses of 3.0, 3.5 and $4.0 \mathrm{kGy}$ did not favour the preservation of pepper. Throughout the preservation for the percentage rot of pepper, it was discovered that the gamma radiation was able to preserve it at optimum dose of $1.0 \mathrm{kGy}$. This is seen in Fig.10. It was also observed that the gamma radiation extends the shelf-life of Capsicum annuum linn (Sombo) and Capsicum frutescens linn (Atarodo-Ibadan local) more than the Capsicum frutescens linn (Atarodo-Hausa type).

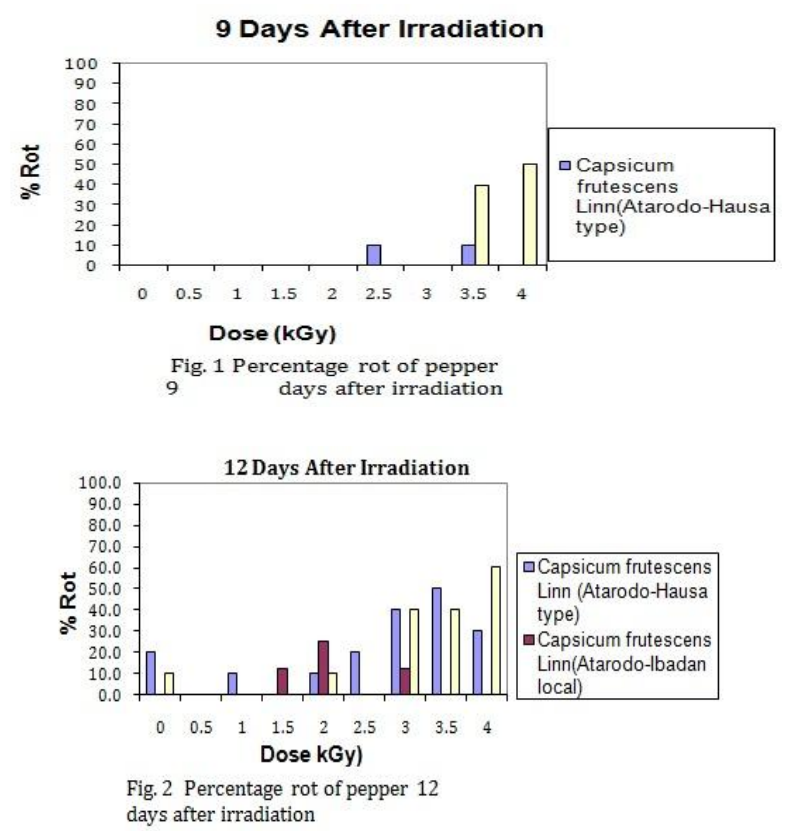

www.iosrjournals.org 

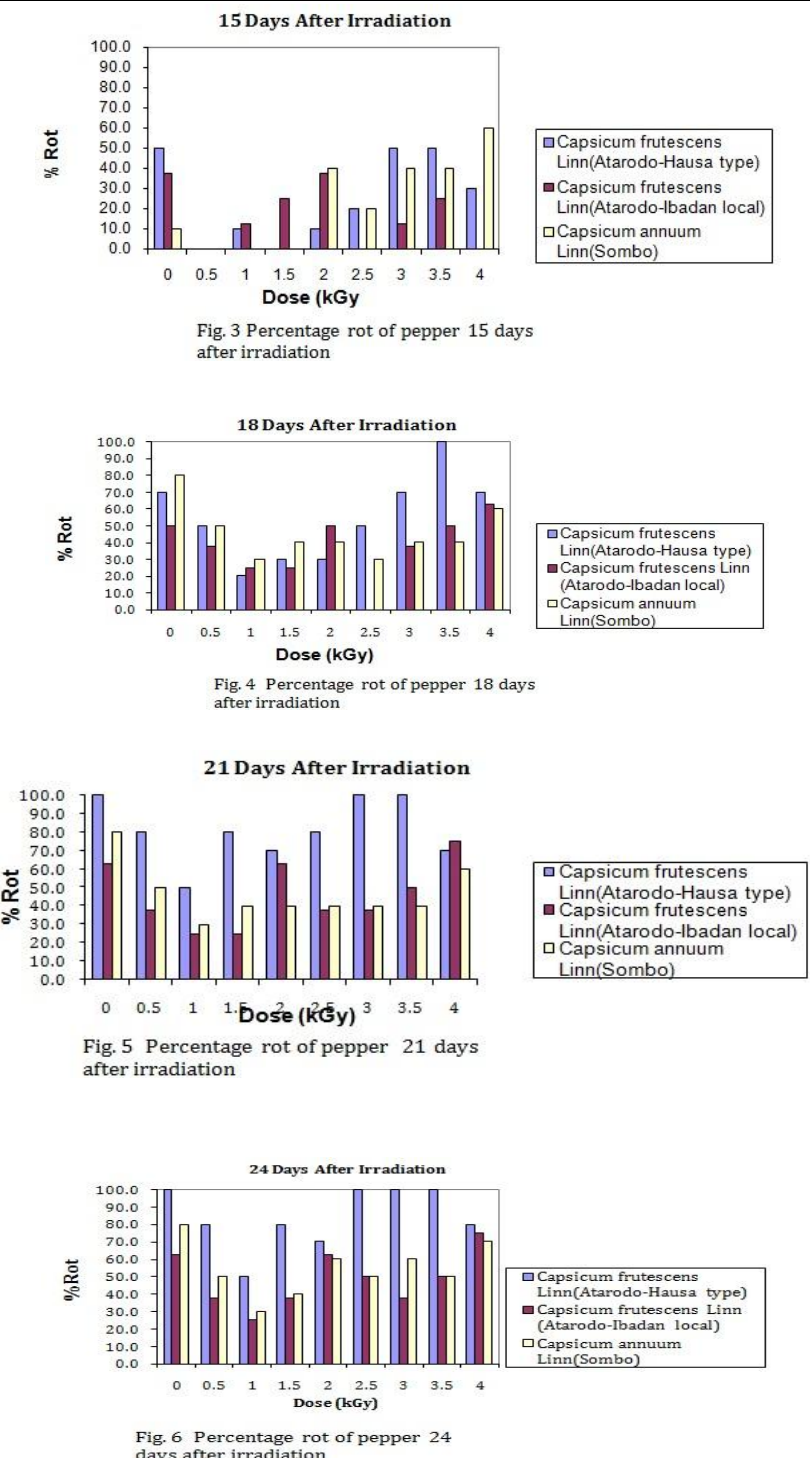

Fig. 6 Percentage rot of pepper 24
days after irradiation

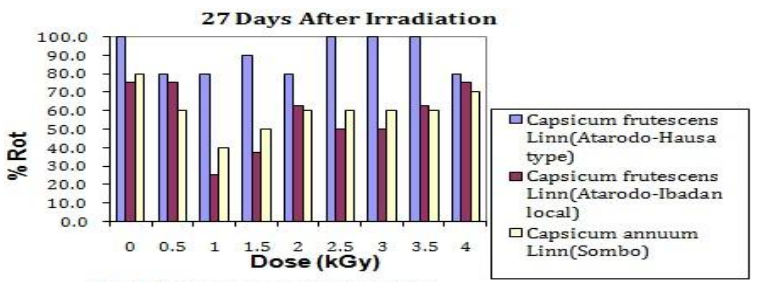

Fig. 7 Percentage rot of pepper
27 days after irradiation

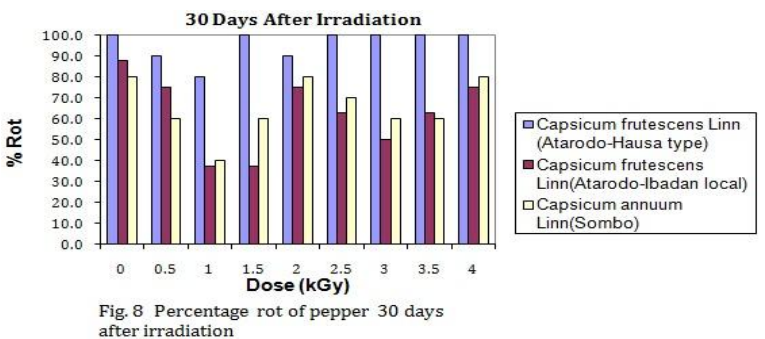

Pepper 30 days 

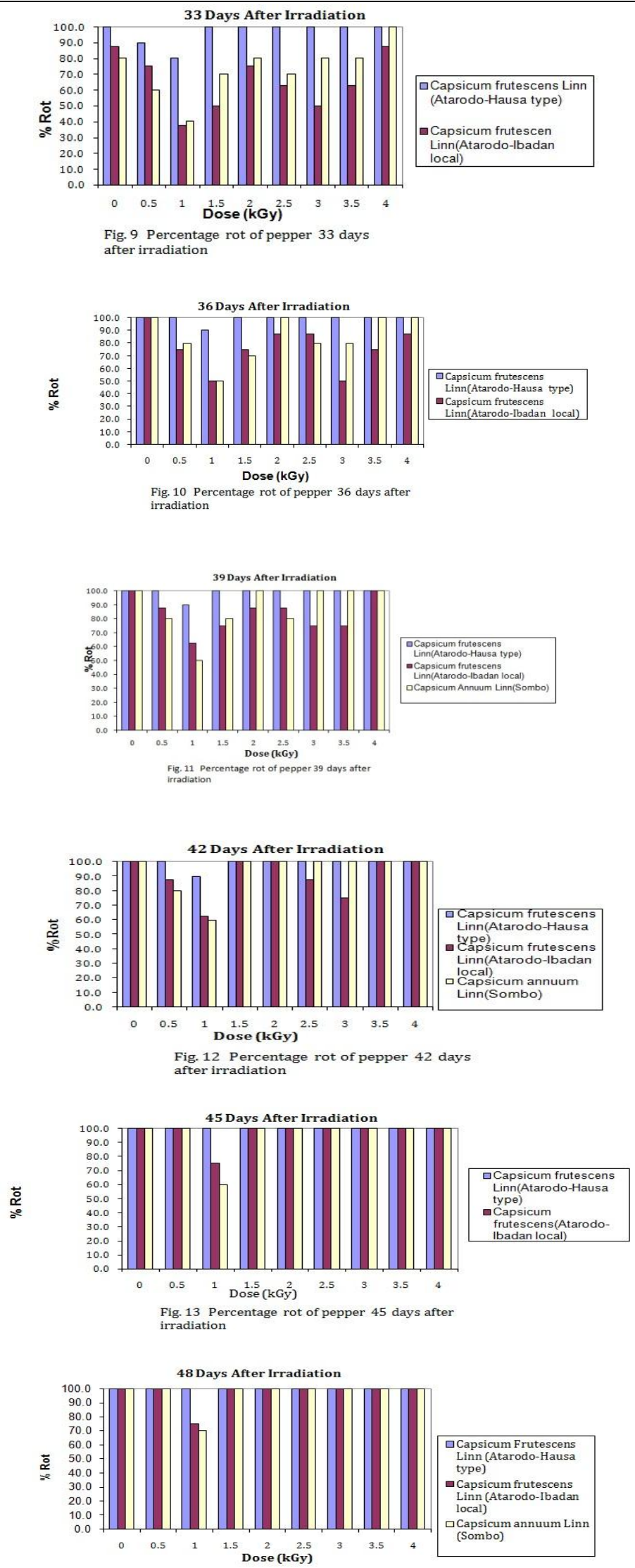

Fig. 14 Percentage rot of pepper 48 days after
irradiation 

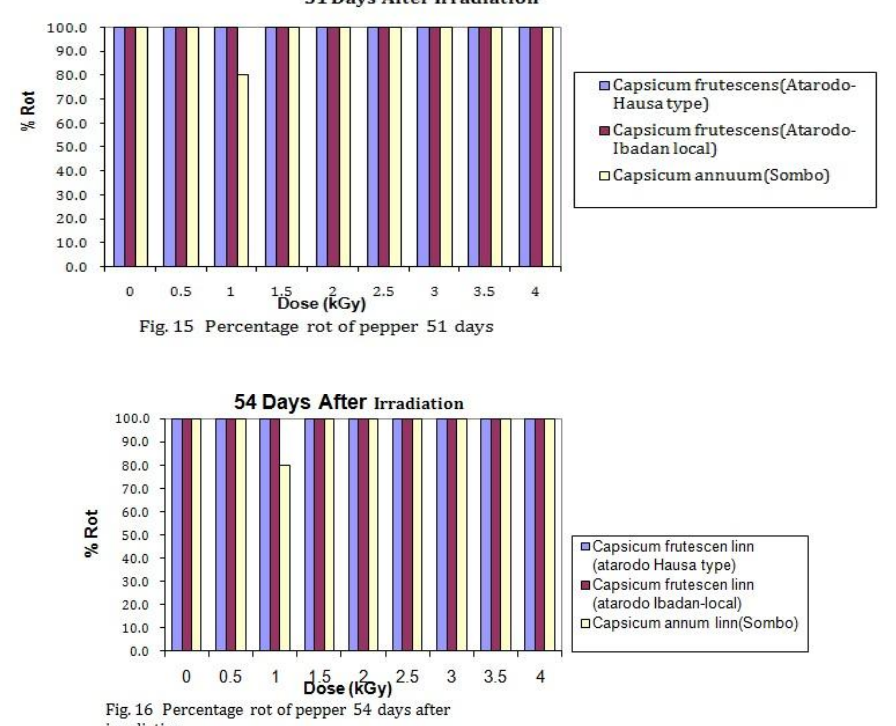

IV. Conclusion

From the results obtained, the following conclusions were made:

The gamma radiation was able to extend the shelf-life of Capsicum annuum linn (Sombo) for fifty-four days, Capsicum frutescens linn (Atarodo-Hausal type) for forty two days and Capsicum frutescens linn (Atarodo-Ibadan local) for forty-eight days. The gamma radiation also extended the shelf-life of the two species of pepper with the optimum dose of $1.0 \mathrm{kGy}$. Food irradiation is a technology that can be safely used to reduce food losses due to deterioration and to control contamination causing illness and death.

\section{Acknowledgement}

The Authors are indeed very grateful to the Director of Centre for Energy Research and Development for the use of research facilities.

\section{Reference}

[1] Olorunda, A.O. and Aboaba, F.O., (1977). Food preservation by Ionizing radiation in Nigeria. Vol.1 IAEA- pp221- 227.

[2] Gee-Harold, Mc (2004). Books for a better knowledge of Ingridients. On food and cooking MIR publishers, London.

[3] Geneva, (1999). Food borne disease: 'a focus health education'. Vol. 2 pp299-313.

[4] Dietz, V., Mead, P.S., Slutsker, L. (2008). Food Related illness and death in the United States, Centres for Disease Control and Prevention 'Vol. 5'. Population reference Bureau, http://www/prb.org.

[5] Glubrecht, H. (1978). 'Basic effects of radiation on food matter'. Proceedings of a symposium Wageningen on food preservation by irradiation Vol. 29. Pp 238.

[6] Hulme, A.C. (1971). The biochemistry of fruits and their products. Vols. I and II, Academic Press, London.

[7] Grosch, D.S. and Hopwood, L.E. (1979). Biological effects of radiation, second edition, Academic press. pp 97. 